\author{
Andrzej T. Jankowski, Marek Ruman \\ University of Silesia - Faculty of Earth Sciences - Department of Physical Geography \\ - Laboratory of Hydrology and Water Management of Urbanized Areas \\ 41-200 Sosnowiec, 60 Będzińska St.,
}

\title{
WATER LEVEL FLUCTUATIONS IN THE TURAWA RESERVOIR IN RELATION TO THE TOURIST USE OF THE WATER BODY*
}

\begin{abstract}
The aim of the paper is to assess the fluctuations of water levels in the Turawa Reservoir ( $\left.50^{\circ} 43^{\prime} \mathrm{N}, 18^{\circ} 08^{\prime} \mathrm{E}\right)$ in relation to the tourist use of the water body. The reservoir is situated within the macroregion of the Silesian Lowland in the mesoregion of the Opole Plain. In administrative terms, the reservoir is situated in the pole Province within the borough of Turawa. In hydrological terms, in turn, it is situated in the catchment area of the Mała Panew river, which belongs to the basin of the Odra river. The Turawa Reservoir was opened for use in 1938, and in 1948 it was filled with water to its maximum for the first time. At present, the surface area of the reservoir, when it is filled with water to its maximum, is about $20.8 \mathrm{~km}^{2}$, its volume $99.5 \mathrm{mln} \mathrm{m}^{3}$, and its depth exceeds 13 meters. In the period of hydrological years 1976-2000 water levels in this reservoir were characterized by high, unnoticed in natural conditions, amplitudes of changes reaching $6.99 \mathrm{~m}$. Anthropogenically stimulated fluctuations in the water level result in conflicts in terms of tasks and functions that the Turawa Reservoir was designed for. Changes in the level of the water surface in the Turawa Reservoir resulted from the impact of the natural factors (thaw and rainfall related high water levels), as well as anthropogenic ones (the need to improve sailing conditions, water supply for industrial and municipal needs). Decreasing the fluctuations of water levels in the Turawa Reservoir is necessary in order to maintain its tourist-recreational functions and keep the ecological condition of its waters at the appropriate level.
\end{abstract}

Key words: limnology, water reservoirs, retention changes, tourism

* Scientific work financed by fund for scientific research in the years 2006-2007 as a research project no. N306 034 31/2179 
The Turawa Reservoir $\left(50^{\circ} 42^{\prime} 27^{\prime \prime}\right.$ to $50^{\circ} 44^{\prime} 32^{\prime \prime} \mathrm{N}, 1^{\circ} 04^{\prime} 51^{\prime \prime}$ to $\left.18^{\circ} 10^{\prime} 59^{\prime} \mathrm{E}\right)$ is situated in the natural extension of the valley of the Mała Panew River, a part of the mesoregion of the Opole Plain. The features of the vicinity of the Turawa Reservoir are of flat-plain nature with extensive dune fields formed by sands of water-glacial origin. The terrain is flat or slightly undulating. Elements that diversify the features include postglacial morainic hills (Fig 1). In administrative terms, the reservoir belongs to the Opole Province and is situated within the boroughs of Turawa and Ozimek.

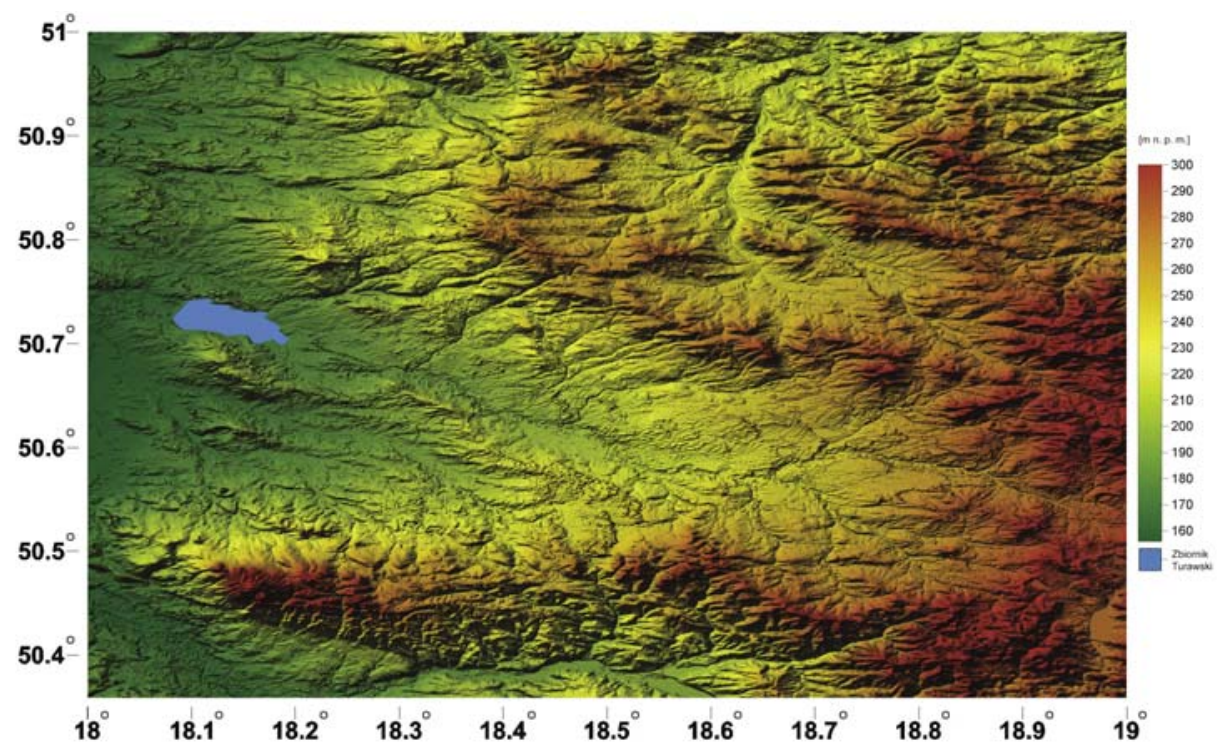

Fig. 1. Situation of the Turawa Reservoir in the digital terrain model (own compilation).

The earliest historical records regarding construction of the reservoir date back to the early 20th century. In late 1903 the beginning of field work in the valley of the Mała Panew River was reported. The construction work which was carried out at that time would later become the foundation of the dam. Actual work, however, did not start until more than 30 years later (Świerc 1992). Construction work of the reservoir in Turawa started in July 1933 and ended in late autumn of 1936. In 1933 the first map was compiled presenting the regions of the Mała Panew valley that would be taken up by the reservoir to be built (Fig. 2). 


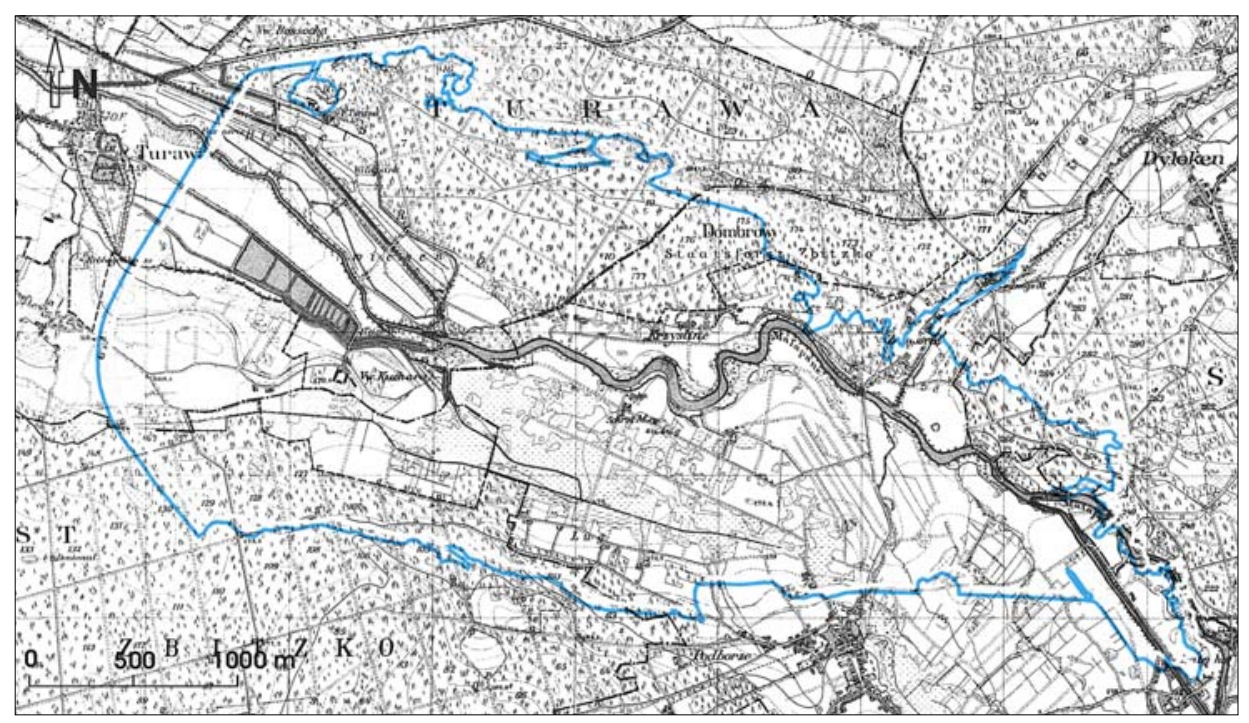

Fig. 2. Planned areal extent of the Turawa Reservoir (based on Staubacken an der Malapane bei Turawa..., 1933)

Before building the Turawa Reservoir, the land situated south of the Mała Panew River had been used mainly in agriculture as fields, wet meadows and pasture land. The land situated north of the river, in turn, had been almost entirely afforested, mainly with pinewoods (Teisseyre 1983). Roots remaining of those trees were not removed during the construction of the reservoir. These roots still exist in the bottom of the reservoir and can be noticed in autumn and winter when the water level is low (Photo 1).

The reservoir was opened for use in 1938, although construction of some objects was still unfinished (Cyberski 1984; Król et al. 1999). During the first years of use of the reservoir, its maximum volume was $62 \mathrm{mln} \mathrm{m}^{3}$ (Ihatowicz 1946). After construction of side banks, backwater banks and the pumping station had been completed in 1948, the Turawa Reservoir was filled with water to its limits for the first time (Król et al. 1999). At present, when the reservoir is filled with water to its maximum, its surface area reaches $20.8 \mathrm{~km}^{2}$, its volume $95.5 \mathrm{mln} \mathrm{m}^{3}$ and its depth exceeds 13 meters. The area of the catchment, up to the front dam of the reservoir, covers $1,423 \mathrm{~km}^{2}$ (Szturc et al. 1999). The reservoir is fed by waters of the rivers Mała Panew, Libawa and Rosa, which flow into it from the south-east, north-east 
and east, respectively. The Turawa Reservoir is one of the largest dam reservoirs in Poland. In terms of total volume and area at the maximum damming, it is 10 th and 8th largest reservoir, respectively. It is the third oldest object of that type, after the Otmuchów and Rożnów reservoirs (Maty Rocznik Statystyczny Polski 2007).

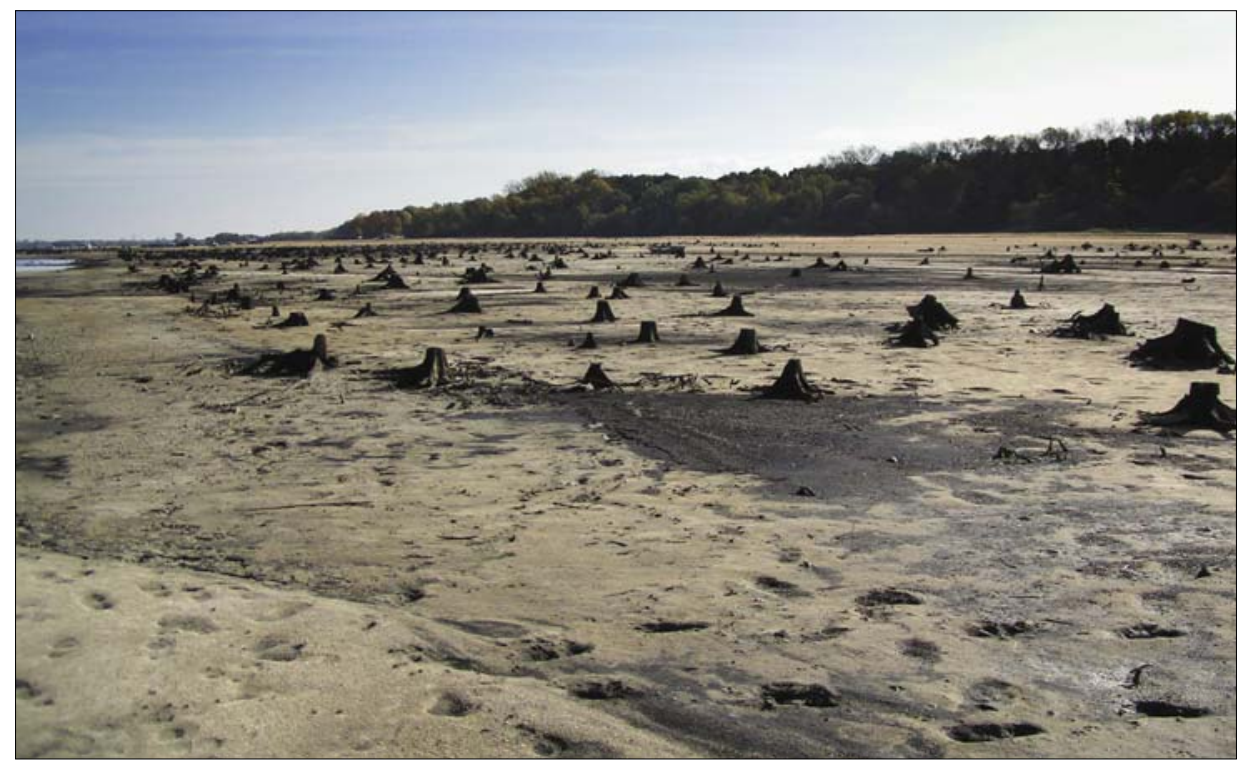

Photo 1. Exposed bottom of the Turawa Reservoir - December 2006 (Photo by M. Ruman)

The functions and importance of the reservoir were defined as early as during its construction in 1933-1939. The reservoir was built in order to overcome shortages of water in the Odra river, so that the river could be used for transportation. Besides water retention, the Turawa Reservoir was also expected to serve recreational functions (Świerc 1992). In 1937, one year before making the reservoir available, its functionality was extended. Construction of a power station was planned, which would supply the neighboring area with energy, and the strategic (military-defensive) function of the reservoir was pointed out (Cyberski 1984). In the late part of 1944, Germans included the Turawa Reservoir into one of their "rings" that was supposed to provide effective protection for the city of Opole (Świerc 1992). 
The Turawa Reservoir and the Mała Panew river, on which it is situated, make up a system where both components have an impact on the natural environment. Because of man's economic activities, the reservoir was adapted so as to serve multiple functions (Ruman et al. 2005).

Currently, the reservoir serves the following functions (Malarski 2002): a) retains water reserves, regulates water level during rainfall, thaws and droughts, and influences the level of underground waters; b) supports the Opole section of the upper Odra with water transfers for the needs of navigation along the Odra; c) enables recreation, relaxation and water sports as well as passenger navigation; d) provides water for farming and public utilities in the catchment area of the Mała Panew; e) allows for intake of large amounts of water by Power Station "Opole"; f) regulates the level of waters in the catchment of the Mała Panew for the needs of flood protection; g) allows for fishery management as well as professional and amateur fishing; h) ensures correct functioning of the water power station built in the embankment crown; i) influences irrigation of the near-bank farming and forest grounds and their microclimate; $j$ ) collects sewage and waste from industry, public utilities and farming, as well as waste from numerous facilities situated near the reservoir; k) naturally purifies the sewage flowing through the water body.

Due to its natural and scenic values, the Turawa Reservoir is very popular in terms of tourism and recreation. A large surface of the reservoir makes excellent conditions for fishing, canoeing and many other water sports (Szopa L. 2005). The Turawa Reservoir is used by the Regional Water Sports and Training Center and "Yachting Club" of LOK in Turawa. There are two sections in the club: sailing and motorboat. Attempts are also being made to start water scooter, water skiing and surfing sections. In winter, when the reservoir is frozen, it attracts fans of ice sailing (Ruman, Rzętała 2005). There are extensive tourist facilities around the reservoir. In 2006 at the Turawa Reservoir, there were 9 year-long recreational centers with 690 beds and 19 seasonal centers with 1,214 beds (acc. to data by the borough office). Because of the deteriorating ecological condition of the water body, falling numbers of tourists staying at the reservoir have been observed as well and decreasing accommodation facilities; their current use is estimated at about 30\% (Ruman 2007). The deteriorating ecological condition of the Turawa Reservoir is to a large extent 
influenced by high fluctuations of its water level; these are among the highest values observed in anthropogenic reservoirs in Poland.

Water level fluctuations in lakes are related to climatic fluctuations and the character of underground alimentation (Choiński 1995), while in case of anthropogenic reservoirs they depend directly on alimentation volume (rainfall, drainage of underground waters, water transfers), and indirectly on the area of the catchment, morphometry of the reservoir basins, character of circulation, hydrogeological conditions of the surrounding area and directions of water management (Rzętała 1997; Machowski, Ruman, Rzętała 2005). In most cases anthropogenically forced water circulation, mainly based on controlling the volume of its outflow, results in an increase in the range of seasonal and short-term fluctuations of water levels (Jankowski, Rzętała 1997).

Multiple functions of the Turawa Reservoir and following the directions of water management have become the source of problems in its management followed by high fluctuations in its water levels. In the period of hydrological years 1968-2006 water levels in this reservoir were characterized by high amplitudes of changes reaching $6.99 \mathrm{~m}$. (Fig. 3). Changes in the water level resulted in changes in its retention (Fig. 4.). In the period of hydrological years 1968-2006, the lowest retention was at $7.6 \mathrm{mln} \mathrm{m}^{3}$ (7\% of total volume), and the highest was at 96.8 $\mathrm{mln} \mathrm{m}^{3}$, (90\% of total volume), which gives an amplitude of $89.2 \mathrm{mln}$ $\mathrm{m}^{3}$. In the period under discussion, the lowest volume of the reservoir was reported in November and December (about $28 \%$ of total volume), and the highest volume in May (about 70\% of total volume).

Anthropogenically stimulated fluctuations in the water level result in conflicts in terms of tasks and functions that the Turawa Reservoir was designed for. Excessive outflow and intake of water in the autumn-winter season lowers the water to the level at which the use of the Turawa Reservoir for recreation and relaxation becomes seriously hindered (Photo 2).

The exposed muddy bottom makes it impossible to reach the waters of the reservoir at that time. Fishing is only possible, but is limited to the crown of the dam. In winter, when the reservoir is frozen, fluctuations of the water level cause a lot of dangers and hindrances. When the water level rises in the reservoir, ice dams on the banks of the reservoir and makes it impossible to do ice sailing or fishing (Photo 3). When the water level drops rapidly, in turn, an air layer is formed between the ice layer and the water level, which is very dangerous for unaware tourists. 


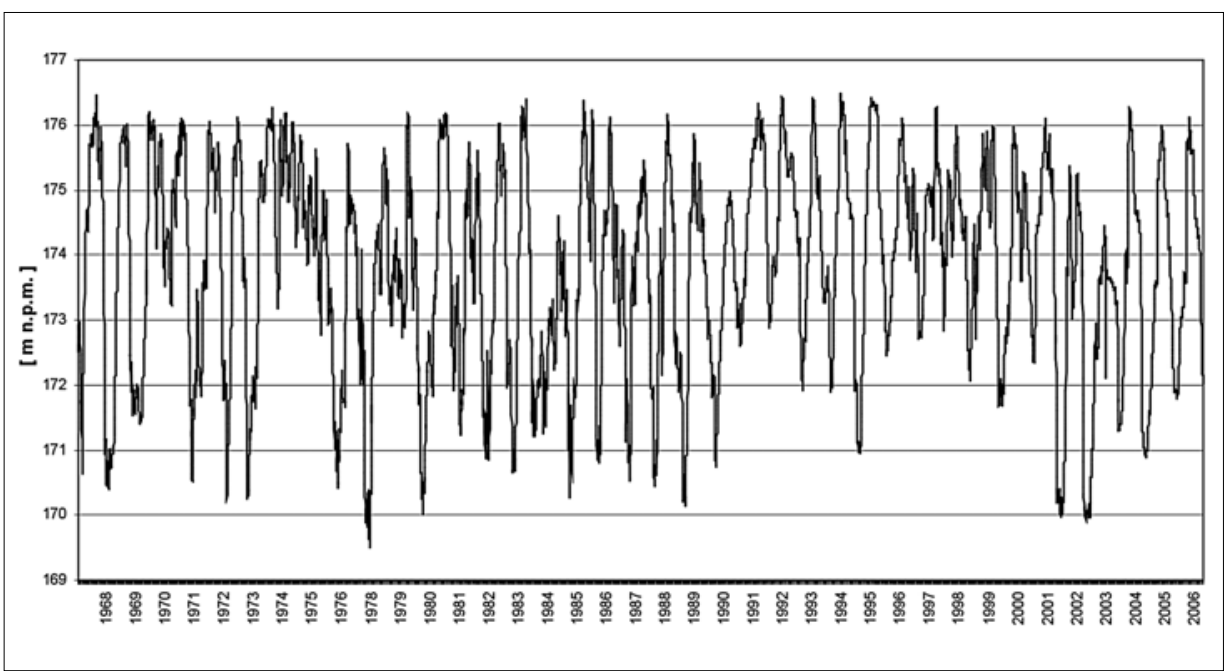

Fig. 3. Daily water levels in the Turawa Reservoir in the period of hydrological years 1968-2006 (own compilation based on data by RZGW)

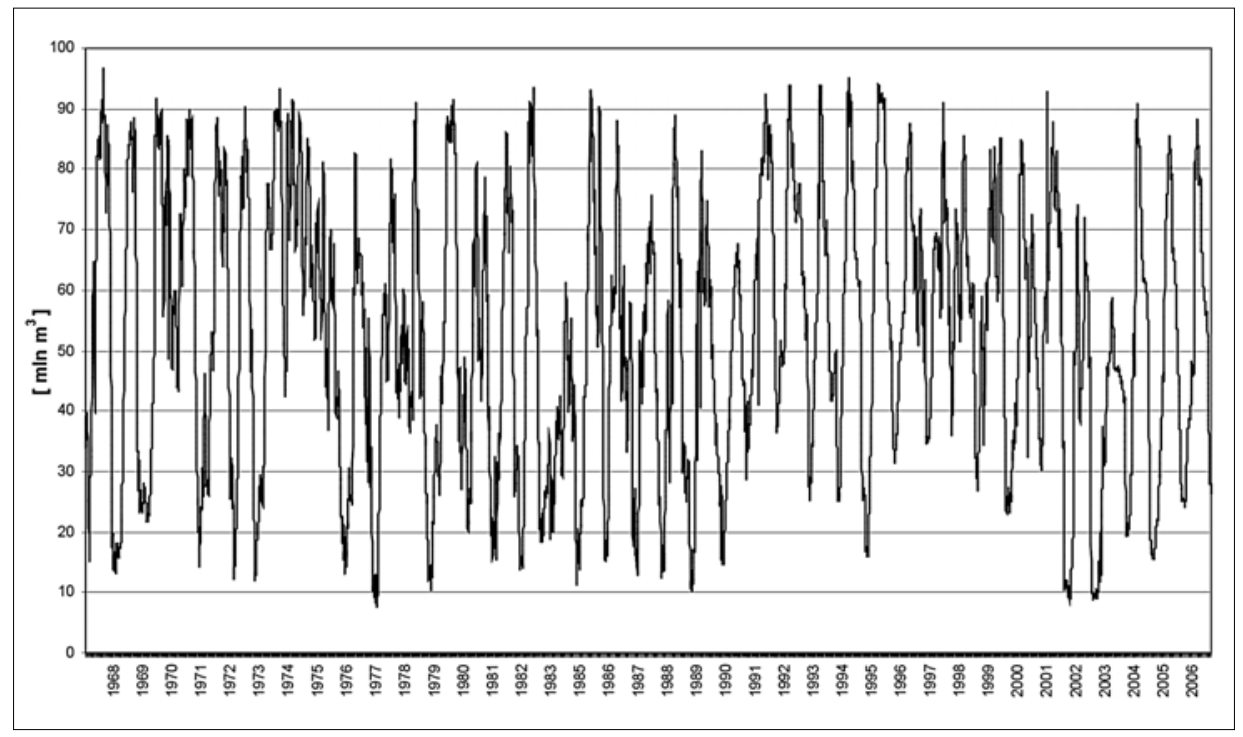

Fig. 4. Daily water retention in the Turawa Reservoir in the period of hydrological years 1968-2006 (own compilation based on data by RZGW) 


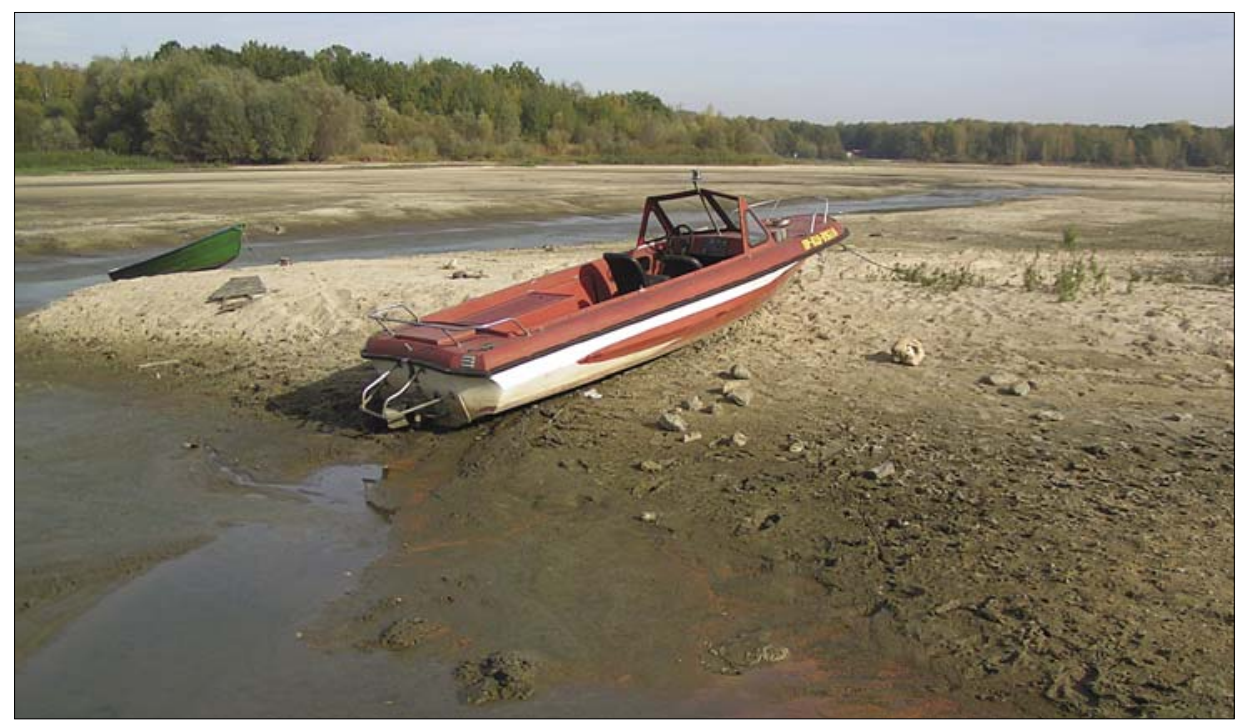

Photo 2. Low water levels hinder the recreational use of the Turawa Reservoir - October 2006 (Photo M. Ruman)

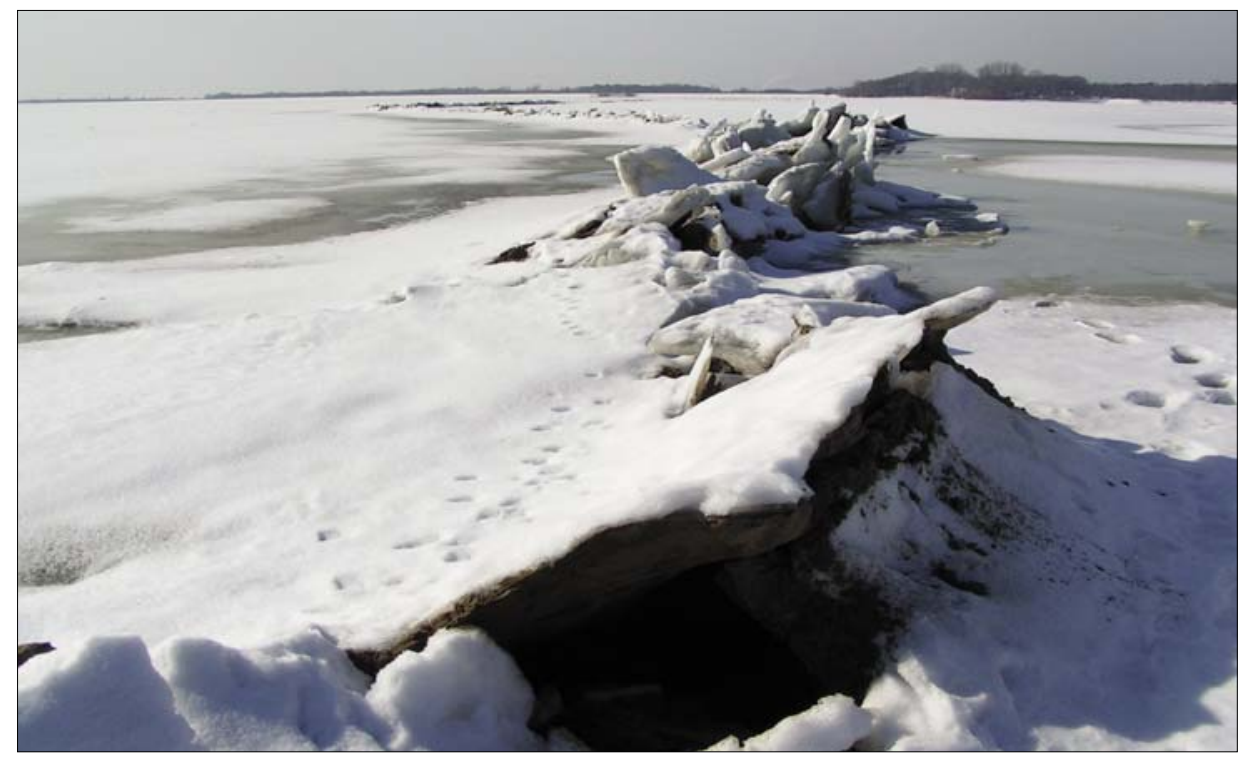

Photo 3. Damming of ice cover in the Turawa Reservoir - February 2006 (Photo M. Ruman) 
Such significant changes in the volume of the reservoir make fish farming difficult (problems to keep the number and health condition of fish at a desired level) and decrease the aesthetic value of the vicinity (Jankowski, Rzętała 1997; Machowski, Ruman, Rzętała 2005). During low water levels, the bank zone moves towards the inside of the reservoir resulting in bottom exposure (Fig. 5, Fig. 6).

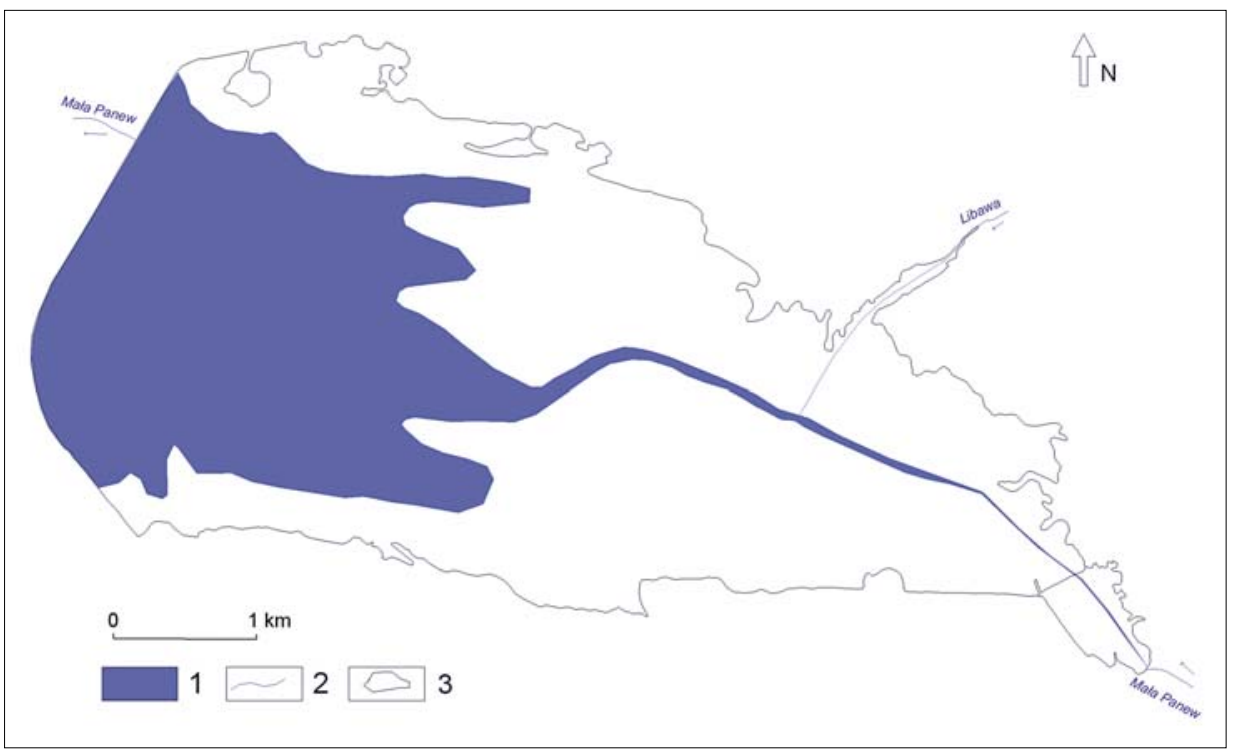

Fig. 5. Changes in the surface area of the Turawa Reservoir (own compilation) 1 - extent of the reservoir on November 3, 2004 (170.88 m a.s.l.) marked basing on the calculations using the GPS receiver, 2 - water streams 3 - extent of the reservoir at normal water damming (176.35 m a.s.l.)

The surface area of the reservoir decreases to about $8 \mathrm{~km}^{2}$ during the lowest water levels, which is about $38 \%$ of the total surface area at $20.90 \mathrm{~km}^{2}$. Exposure of the reservoir bottom has a negative effect on the quality of water. Intensive decomposition and mineralization of organic matter occurs. Mineral salts and humic substances that are created as the result of this process cause - directly and indirectly (growth of algae and bacteria) - deterioration of water quality when the reservoir bottom is fully covered with water again (Pasternak 1984). That, in turn, intensifies eutrophication in summer, which makes the tourist use of the reservoir impossible. Algal blooms result in forma- 
tion of tocsins, which cause deterioration of taste and smell values of the water. As the result, bathing in the reservoir is prohibited every year (Ruman 2005; Machowski, Ruman, Rzętała 2006; Ruman 2006). When a low water level lasts too long, the exposed part of the bottom is overgrown by land vegetation, which is then decomposed after the water level rises again. Also, heavy metals are washed out from the bottom of the reservoir. During the highest levels, in turn, floodings of the neighboring areas occur. It seems necessary to decrease the water level fluctuations in the Turawa Reservoir in order to maintain its tourist-recreational functions and keep the ecological (sanitary) condition of its waters at the appropriate level.

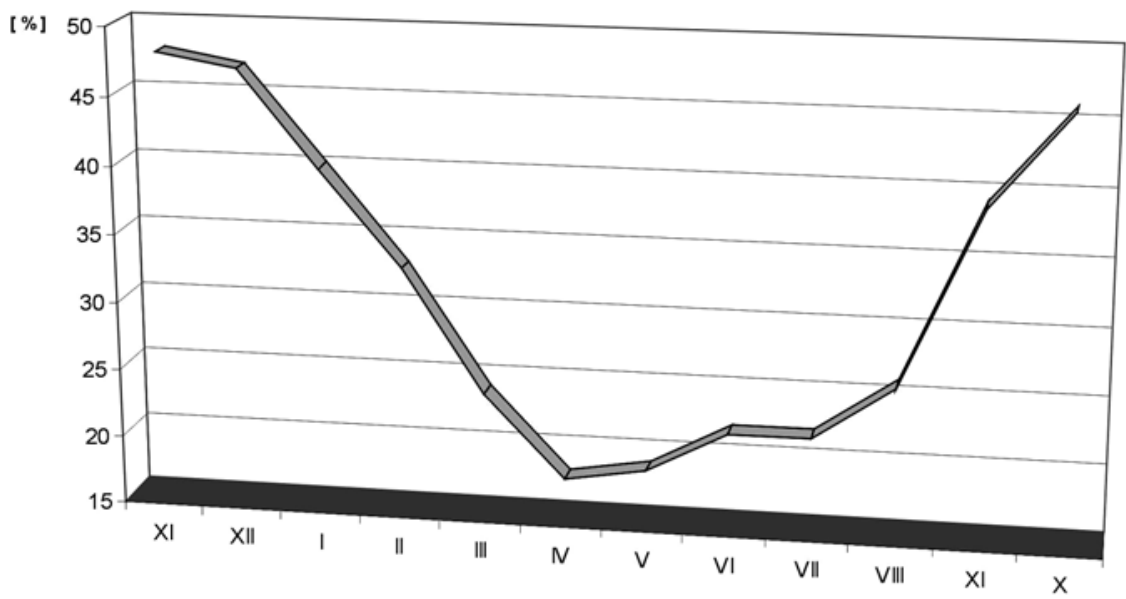

Fig. 6. Average monthly exposure of the bottom of the Turawa reservoir in the period of hydrological years 1996-2005 (own compilation)

\section{REFERENCES}

Choiński A., 1995, Zarys limnologii fizycznej Polski [The outline of physical limnology of Poland; in Polish], Wydawnictwa UAM, Poznań. p. 298.

Cyberski J., 1984: Wstępne wiadomości o zbiornikach retencyjnych w Polsce [Indroductory information about storage reservoirs in Poland; in Polish], Czasopismo Geograficzne LV, t. 3, Wrocław. p. 293-299.

Ignatowicz P., 1946, Droga wodna Odry. Charakterystyka techniczna [Water Odra River way. Technical characteristic; in Polish], Gospodarka Wodna, nr 2/1946. Warszawa p. 87-100. 
Jankowski A. T., Rzętała M., 1997, Problemy wykorzystania retencji zbiornikowej w warunkach silnej antropopresji [The problem of the use of reservoir retention in the conditions of high anthropopression; in Polish], [in:] Konferencja naukowa „,Wptyw antropopresji na jeziora”. Poznań, 2 grudnia 1997 r. ZHiGW IGF UAM, A.Choiński (ed.), Wydawnictwo Domini, Poznań-Bydgoszcz. p. 37-42.

Król P., Dzik G., Bojarski M., 1999, Ocena stanu technicznego zbiorników retencyjnych-Zbiornik Wodny Turawa [The evaluation of the technical state of storage reservoirs - The Turawa water reservoir; in Polish], Wykonawca: Spółka z o. o. Projekty i Konsultacje Geotechniczne, zleceniodawca: ODGW Wrocław.

Machowski R., Ruman M, Rzętała M., 2005, Water stage fluctuations in selected anthropogenic water reservoirs in the upper part of the Odra catchment.] Limnological Review vol. 5 (2005). Faculty of Earth Sciences University of Silesia, Sosnowiec. pp. 145-154.

Machowski R., Ruman M, Rzętała M., 2006, Abiotic manifestations of eutrophication of water reservoirs in cases of extreme agricultural and industrial anthropopressure.] Limnological Review vol. 6 (2006). Polish Limnological Society, Poznań. pp. 179-186.

Malarski P., 2002, Wybrane kompetencje, zadania i obowiązki organów administracji publicznej w zakresie gospodarki wodnej i ochrony środowiska wodnego [Chosen authorities, tasks and duties of the public administration authorities in the fields of water management and conservation of water environment; in Polish], [in:] Czystość wody zbiornika Turawa gwarancjq dobrego wypoczynku. Instytut Ślaski [Clearness od water of Turawa reservoir quarantee good refreshment; in Polish], Turawa - Opole. p. 55-59.

Maty Rocznik Statystyczny Polski 2007 [Consise Statistical Yearbook of Poland 2007; in Polish], Główny Urząd Statystyczny. ZWP. Warszawa, p. 722.

Pasternak K., 1984, Zmiany w chemicznych i biologicznych stosunkach środowiska wodnego rzeki jako rezultat oddziaływania zbiorników retencyjnych [Changes in chemical and biological relationships of the water environment of a river as a result of the influence of storage reservoirs; in Polish],] Czasopismo Geograficzne. Tom LV. Polskie Towarzystwo Geograficzne, Wrocław. p. 365-377.

Ruman M., 2005, Abiotyczne przejawy eutrofizacji zbiornika Turawskiego [Abiotic manifestations of the eutrophication of the Turawa reservoir; in Polish], [in:] III Konferencja Zasoby Wodne Triasu Opolskiego i Ekologia Jezior Turawskich, Opole-Strzelce Opolskie 2-3 czerwiec 2005 r. p. 223-230.

Ruman M., 2006, Eutrofizacja Zbiornika Turawskiego [Eutrophication of the Turawski Reservoir; in Polish] [in:] Materiaty z I Ogólnopolskiej Konferencji Geografów-Doktorantów, Lublin 12-14 czerwca 2006 r., M. Harasimiuk, (ed.), Uniwersytet Marii Curie-Skłodowskiej, Instytut Nauk o Ziemi, Polska Akademia Nauk, Komitet Nauk Geograficznych, Lublin. p. 65-71.

Ruman M., 2007, Rola Zbiornika Turawskiego w dolinie Małej Panwi [The role of the Turawa reservoir in the Mała Panew river valley; in Polish], [in:] Krajobraz dolin rzecznych. Materiały Polsko-Ukraińskiej Konferencji Naukowej, IX Seminarium Krajobrazowe. U. Myga-Piątek, W. Andrejczuk., (ed.), Komisja Krajobrazu Kulturowego Polskiego Towarzystwa Geograficznego, Sosnowiec, Czerniowce. p. 73. 
Ruman M., Rzętała M., 2005, Zróżnicowanie pokrywy lodowej zbiorników zaporowych Turawa i Kozłowa Góra w latach hydrologicznych 1975-1996. [Variety of ice cover of Turawa and Kozłowa Góra dam reservoirs in hydrological years 1975-1996; in Polish], [in:] Jeziora i sztuczne zbiorniki wodne - procesy przyrodnicze oraz znaczenie społeczno-gospodarcze [Lakes and artificial water reservoirs - natura processes and socio-economic importance; in Polish], ed. by A. T. Jankowski, M. Rzętała. Uniwersytet Ślasski - Wydział Nauk o Ziemi, Polskie Towarzystwo Limnologiczne, Polskie Towarzystwo Geograficzne - Oddział Katowicki, Sosnowiec p. 189-196.

Ruman M., Rzętała M., Schröder K., 2005, Społeczno-gospodarcze znaczenie zbiornika Turawskiego [Social and economic importance of the Turawa Reservoir; in Polish], [in:] $Z$ badań nad wptywem antropopresji na środowisko. T.6. [From research over influence on environment anthropopressure. T.6.; in Polish], ed. by R. Machowski, M. A. Rzętała. SKNG UŚ, WNoZ UŚ, Sosnowiec. p. 141-145.

Rzętała M., 1997, Uwarunkowania stanów wody w wybranych zbiornikach antropogenicznych województwa katowickiego [Conditoning of the water state in the chosen anthropogenic reservoirs of the Silesia Province; in Polish] [in:] 46 Zjazd Polskiego Towarzystwa Geograficznego „Przyrodnicze i spoteczne walory Mazowsza $w$ dobie restrukturyzacji” [46 convention of Polish Geographical Society ,Natura and social values of Mazowsze in day of restructuring”; in Polish], Oddział Akademicki PTG, IGiPZ PAN, WGiSR UW, Rynia-Warszawa. p. $117-120$.

Staubacken an der Malapane bei Turawa. Zusammendruck aus den Messtischblattern nr 3084, 3085, 3143 u. 3144. 1933. 1: 25 000, Hergestellt vom Reichsamt fur Landesanfnahme Berlin.

Świerc W., 1992, Monografia Turawy [Monograph Turawa; in Polish], Fala, Turawa. p. 3-5.

SZOPA L., 2005, Turystyka kajakowa na Ślasku Opolskim [Canoeing tourism in the Opole Silesia; in Polish], [in:] Ślask Opolski. Wybrane zagadnienie turystyki na Ślasku Opolskim [Opole Silesia. Chosen questions of tourism; in Polish], 1-2/2005 (54-55). Państwowy Instytut Naukowy - Instytut Ślaski, Opolu. p. 101-102.

Szturc J., Ośródka K., Jurczyk A., Pisarska D., 1999, Średnioterminowa prognoza doptywu do zbiornika $w$ Turawie [The average time limit forecast of the inflow to the reservoir in Turawa; in Polish], IMiGW Oddział w Katowicach, Biuro hydrologiczno-meteorologiczne. Katowice.

Teisseyre A. K., 1983, Osady denne Jeziora Turawskiego w świetle badań geologicznych [Bottoms of the Turawa Lake in the light of geological research; in Polish], Geologia Sudetica 18 (1), p. 21-60.

English translation: Robert Górniak 